Dhaka Univ. J. Biol. Sci. 28(1): 71-81, 2019 (January)

\title{
BETA-LACTAMASE-PRODUCING ESCHERICHIA COLI IN BANGLADESH: THEIR PHENOTYPIC AND MOLECULAR CHARACTERISTICS
}

\author{
SunjuKta Ahsan* and Riajul Islam \\ Department of Microbiology, University of Dhaka, Dhaka-1000, Bangladesh
}

Key words: Beta-lactamase, Escherichia coli, Molecular characteristics

\begin{abstract}
The emergence and rapid dissemination of beta-lactamase-producing E. coli is now a worldwide problem. A total of $45 \mathrm{E}$. coli obtained from clinical specimens from a medical service centre in Dhaka were selected for this study. Test E. coli exhibited variable resistance to $3 \mathrm{rd}(71.7-97.8 \%, \mathrm{n}=48)$ and 4 th $(78 \%$, $\mathrm{n}=48$ ) generation beta-lactam antibiotics, with $72 \%$ sensitivity to Carbapenem. Analysis of co-resistance indicated that $33.3 \%$ of $E$. coli $(n=48)$ were co-resistant to beta-lactams and ciprofloxacin. ESBL producers were predominant comprising of $84.7 \%$ E. coli. Among them, $22.7 \%$ contained blateм, $24.2 \%$ contained blactx-м, 4.3\% contained blashv and 9.1\% contained blaoxA-1 genes. A total of $25.75 \%$ isolates were metallo beta-lactamase producers. Of these, $1.5 \%$ of E. coli strains contained New Delhi metallo beta-lactamase gene and 6\% contained AmpC gene. Multiple beta-lactamase genes were detected in some test isolates; $6.7 \%$ isolates contained $4,20 \%$ contained 3 and $73.3 \%$ contained 2 beta lactamase genes. Fifty per cent of the $E$. coli contained plasmids of variable sizes. In addition, a total of $39 \%$ of the E. coli contained Class 1 integron. The increasing trend in beta-lactam resistance is of public health concern as it limits treatment regime and indicates to the need of continuous monitoring of resistance pattern.
\end{abstract}

\section{Introduction}

Beta lactamase resistance in Gram-negative bacteria is increasingly reported in different countries of the world. In Bangladesh, beta-lactam antibiotics are readily available over-the-counter and are routinely used for treating infections. This has led to dramatic increase in resistance to beta-lactam agents. Beta-lactamase encoding genes are plasmid-borne and can degrade a range of antibiotics including penicillins, cephalosporins, and aztreonam and are inhibited by clavulanic acid (CA) ${ }^{(1)}$. The detection of betalactam related genes is challenging(2) and requires nucleic acid amplification and sequence analysis. In earlier studies researchers had investigated the presence of TEM, SHV, OXA and CTX-type enzymes ${ }^{(3,4)}$ and found CTX-M enzymes as the most prevalent types ${ }^{(4,5)}$. The genes for beta-lactamase production are usually found in mobile genetic elements $^{(6)}$. Often, ESBL producers are co-resistant to other antibiotics which is of concern

\footnotetext{
*Author for correspondence: 〈Sunjukta@du.ac.bd>.
} 
in deciding treatment strategies(7). Escherichia coli is responsible for causing diarrhoeal disease and UTI. It is also one of the most prevalent ESBL producer known ${ }^{(8,3)}$, thereby making treatment with beta lactam antibiotics difficult. The present study was undertaken to determine the molecular and phenotypic characteristics of ESBL producing clinical E. coli in order to characterize the major determinants for ESBL phenotype.

\section{Materials and Methods}

A total of 59 E. coli isolated from urine were investigated. E. coli ATCC 25922 was used as control for antibiotic sensitivity tests and E. coli V517 was used as a positive control for plasmid extraction.

All samples were collected by the trained physicians/phlebotomists after having consent from the patients. Bacteria were isolated from the collected samples as part of the diagnostic tests requested by the patients. Isolated and identified bacteria were given code numbers and stored in glycerol broth at $-20^{\circ} \mathrm{C}$ for this study.

Isolates were identified in the laboratory by their cultural characteristics on MacConkey and Eosin Methylene Blue agar. Biochemical characteristics were determined by using Kligler Iron Agar, Citrate utilization agar, Motility Indole Urea agar, Peptone broth for Indole production and Oxidase test.

Isolates were subject to antimicrobial susceptibility testing by disk diffusion method (Bauer and Kirby 1969) using commercial antibiotic disks. The antibiotic disks used in this study were amoxicillin $30 \mu \mathrm{g}$ (AML), ampicillin $30 \mu \mathrm{g}$ (AMP), ceftriaxone $30 \mu \mathrm{g}$ (CRO), cefepime $30 \mu \mathrm{g}(\mathrm{CPM})$, cefuroxime $30 \mu \mathrm{g}$ (CXM), cefexime $30 \mu \mathrm{g}$ (CEF), cefotaxime $30 \mu \mathrm{g}$ (CTX) and imipenem $10 \mu \mathrm{g}$ (IPM).

PCR was used for the detection of beta-lactamase genes. PCR primers used in this study are detailed in Table 1.

PCR amplification cycles were carried out by initial denaturation at $95^{\circ} \mathrm{C}$ for $5 \mathrm{~min}$, followed by 35 cycles consisting of denaturation at $95^{\circ} \mathrm{C}$ for $30 \mathrm{sec}$, annealing at $55^{\circ} \mathrm{C}$ for $30 \mathrm{sec}$, extension at $68^{\circ} \mathrm{C}$ for $1 \mathrm{~min} / \mathrm{kb}$ of amplicon and final extension at $68^{\circ} \mathrm{C}$ for $8 \mathrm{~min}$.

Agarose gels of $2.0 \%(\mathrm{w} / \mathrm{N})$ were used for resolution of PCR products.

Plasmid DNA was prepared according to the alkaline lysis method of Birnboim and Doly $(1979)^{(17) .}$

Class 1 integron was detected by PCR by amplification of the integrase gene using intl1 primers (Table 1). 
Table 1. Primers used in this study.

\begin{tabular}{|c|c|c|c|c|c|}
\hline $\begin{array}{l}\text { Target } \\
\text { gene }\end{array}$ & Primers & Sequence $\left(5^{\prime}-3^{\prime}\right)$ & $\begin{array}{l}\text { Amplicon } \\
\text { size (bp) }\end{array}$ & $\begin{array}{l}\text { Annealing } \\
\text { temp. }\left({ }^{\circ} \mathrm{C}\right)\end{array}$ & References \\
\hline Blatem & $\begin{array}{l}\text { TEM F } \\
\text { TEM R }\end{array}$ & $\begin{array}{l}\text { 5'-ATGAGTATTCAACATTTCCG-3' } \\
\text { 5'-CCAATGCTTAATCAGTGAGC-3' }\end{array}$ & 858 & $\begin{array}{l}55 \\
(1 \mathrm{~min})\end{array}$ & (9) \\
\hline Blactx-M & $\begin{array}{l}\text { CTXU1 } \\
\text { CTXU2 }\end{array}$ & $\begin{array}{l}\text { 5'-ATGCTGCAGYACCAGTAARGT-3' } \\
\text { 5'-TGGGTRAARTARGTSACCAGA-3' }\end{array}$ & 593 & $\begin{array}{l}55 \\
(40 \mathrm{sec})\end{array}$ & (10) \\
\hline Blashv & $\begin{array}{l}\text { SHV F } \\
\text { SHV R }\end{array}$ & $\begin{array}{l}\text { 5'-CTTTACTCGCTTTATCG-3' } \\
\text { 5'-TCCCGCAGATAAATCACCA-3' }^{\prime}\end{array}$ & 837 & $\begin{array}{l}55 \\
(30 \mathrm{sec})\end{array}$ & (11) \\
\hline Blaoxa-1 & $\begin{array}{l}\text { OXA 1F } \\
\text { OXA 1R }\end{array}$ & $\begin{array}{l}\text { 5'-AGCCGTTAATTAAGCCC-3' } \\
\text { 5'-CTTGATTGAAGGGTTGGGCG-3' }\end{array}$ & 882 & $\begin{array}{l}55 \\
(30 \mathrm{sec})\end{array}$ & (12) \\
\hline Blakpc-1 & $\begin{array}{l}\text { KPC 5F } \\
\text { KPC 10R }\end{array}$ & $\begin{array}{l}\text { 5'-TGTCACTGTATCGCCGTC-3' } \\
\text { 5'-CTCAGTGCTCTACAGAAAACC-3' }\end{array}$ & 900 & $\begin{array}{l}48 \\
(30 \mathrm{sec})\end{array}$ & (13) \\
\hline Blaampc & $\begin{array}{l}\text { AmpC F } \\
\text { AmpC R }\end{array}$ & $\begin{array}{l}5^{\prime} \text {-CCCCGCTTATAGAGCAACAA-3' } \\
5^{\prime} \text {-TCAATGGTCGACTTCACACC-3' }\end{array}$ & 634 & 55 & (14) \\
\hline Blandm & $\begin{array}{l}\text { NDM F } \\
\text { NDM R }\end{array}$ & $\begin{array}{l}\text { 5'-GGTTTGGCGATCTGGTTTTC-3' } \\
\text { 5'-CGGAATGGCTCATCACGATC-3' }^{\prime}\end{array}$ & 621 & $\begin{array}{l}48 \\
(45 \mathrm{sec})\end{array}$ & (15) \\
\hline Intl & Intl $\mathrm{F}$ InH R & $\begin{array}{l}\text { 5-ACATGTGATGGCGACGCACGA3' } \\
\text { 5-ATTTCTGTCCTGGCTGGCGA3' }\end{array}$ & Variable & 55 & (16) \\
\hline
\end{tabular}

\section{Results and Discussion}

All isolates were found resistant to amoxycillin (100\%) and all except one were resistant to amoxy-clav $(97.2 \%)$. Variable resistance $(71.7-97.8 \%)$ was observed against $3^{\text {rd }}$ generation beta-lactam antibiotics (ceftriaxone, cefixime, cefuroxime, cefotaxime, cefepime and imipenem). About $78 \%$ of the test isolates were resistant to the $4^{\text {th }}$ generation Beta-lactam antibiotic, cefepime. In contrast, $72 \%$ of the isolates were sensitive to Imipenem. The antibiotic susceptibility pattern of the E. coli strains is shown in Fig. 1. Antibiotic resistance is a burning issue in the field of medicine which complicate treatment of infected patients ${ }^{(19)}$. One of the mechanisms by which Gram-negative bacteria acquire resistance to beta-lactam antibiotics is through the production of betalactamases. The present study was conducted to investigate the production of betalactamases by amoxycillin resistant clinical isolates collected from a medical diagnostic center in Dhaka city. All isolates showed relatively greater sensitivity to imipenem when compared to other beta-lactams. This could be attributed to treatment of patients with antibiotics which create selective pressure on isolates and help gaining resistance to the antibiotics they are exposed to. Although ESBLs have been described in different Gramnegative bacteria, Klebsiella pneumoniae and Escherichia coli are the major ESBL-producing microorganisms worldwide ${ }^{(3,20,21)}$.

Of 27 E. coli strains $33.3 \%$ exhibited resistance to penicillins-cephalosporins, carbapenems and ciprofloxacin, 55.6\% were co-resistant to penicillin-cephalosporin and ciprofloxacin whereas $3.7 \%$ was resistant to penicillin-cephalosporin and azithromycin. 
In the present study, $33.3 \%$ of the E. coli exhibited co-resistance to penicillins, cephalosporins, carbapanemes and fluoroquinolones, whereas $55.6 \%$ were resistant to penicillins, cephalosporins and fluoroquinolones. A similar prevalence was reported earlier(22) that found $61.1 \%$ of ciprofloxacin resistant ESBL E. coli. The presence of coresistance in the test isolates which also contained plasmids raises concern over transfer of drug resistance in the environment.

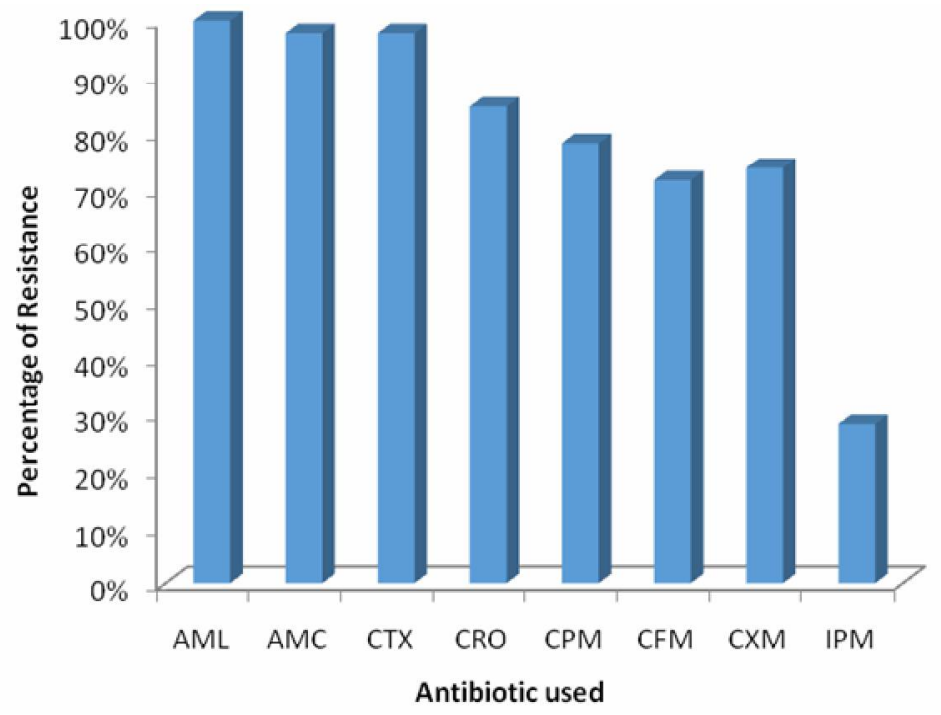

Fig. 1. Resistance of the E. coli isolates against different antibiotics. Amoxicillin (AML), ampicillin $(\mathrm{AMP})$, ceftriaxone $(\mathrm{CRO})$, cefepime $(\mathrm{CPM})$, cefuroxime $(\mathrm{CXM})$, cefexime $(\mathrm{CEF})$, cefotaxime (CTX) and imipenem (IPM).

Based on antibiotic resistance pattern, the isolates were classified into four major beta-lactamase producing classes following Ambler's classification ${ }^{(23)}$. The classification is shown in Table 2. In the present study, $84.7 \%$ of the E. coli were classified as ESBL producers based on Ambler's classification and subsequent molecular confirmation. In a previous report from Bangladesh $43.2 \%$ of $E$. coli were found to be ESBL producers ${ }^{(24)}$. This was followed by reports of 26.9 and 34.1\% ESBL producers by Alim and Mostaqim in 2005 and 2007, respectively(25,26). Later, in 2014, it was reported 11.8\% ESBL producing E. coli isolated from clinical sources ${ }^{(27)}$, followed by a report of $31.9 \%$ ESBL E. coli in $2015^{(28)}$. Clearly a prevalence of $84.7 \%$ ESBL in the present study indicates an alarming rise of ESBL producers in the community. ESBL prevalence varies in different countries with various prevalence being reported from Iran, India and Pakistan ${ }^{(29-35)}$. The present study indicated $28.3 \%$ E. coli that were carbapenem resistant. This finding is a clear contrast to a report by Islam et al. (2015)(28) from Bangladesh who indicated 100\% sensitivity to carbapenem. Once again, there is a rising trend of resistance to 
carbapenems as there was to Beta-lactams. Based on the findings of the present study, carbapenems remain the drug of choice for treatment of E. coli infections.

Table 2. Classification of beta-lactamase producers according to Ambler's classification scheme. ${ }^{(23) .}$

\begin{tabular}{ll}
\hline Class & Isolates of E. coliin the class (n, \%) \\
\hline Class AD (ESBLs) & $19,20,22,26-31,33-35,37-39,42$ and 47-48 (18, 39\%) \\
Class B (Metallo beta-lactamases, MBLs) & $1,3,5,7-8,11,13,16,18,23$ and $25(11,23.9 \%)$ \\
Class C (AmpC) & - \\
Untypeable (Isolates showing & $2,4,9,10,12,14,15,17,21,24,36,40,41,43,44-46$ \\
intermediate susceptibility to & $(\mathrm{n}=17,37 \%)$ \\
carbapenem) & \\
\hline
\end{tabular}

Whether an isolate was a metallo beta-lactamase producing strain was determined(36) by Ambler's classification scheme. Out of 66 isolates, 17 (25.75\%) were MBL producers. Metallo beta-lactamases belong to class B(37) of Ambler's classification scheme. This class is further divided into subclasses B1, B2, and B3, of which Class-B1 enzymes are the most clinically significant( ${ }^{(38-39)}$. New Delhi metallo beta-lactamase enzymes belong to Class B1 and confer resistance to all beta-lactam antibiotics known ${ }^{(40)}$. NDMs are no longer confined to India, Bangladesh or Pakistan ${ }^{(41,42)}$. In the present study, NDM subclass was prevalent among $2.2 \%$ of E. coli. NDM encoding genes are usually located on a readily transferable plasmid(43). It was found that only NDM producing E. coli contained a plasmid, which is in concordance with other findings. This indicated that NDM producing genes were present in the chromosome in high frequency in the present study.

Screening of ESBL-producers by plate-based assay is challenging ${ }^{(2,44)}$. Detection of specific genes by PCR and sequencing are usually conducted for the final confirmation of ESBL production. Molecular characterization of isolates by identifying specific genes with the help of PCR was needed for final confirmation of beta-lactamase production. The association of ESBLs and the presence of TEM, SHV, OXA and CTX-M-type enzymes have been investigated in many studies ${ }^{(3,4)}$. As reported by other researchers in earlier studies $^{(4,5)}$, this study was also found predominance of CTX-M gene $(34.8 \%)$ closely followed by TEM genes (32.6\%). The CTX-M type of beta-lactamase represent a rapidly emerging group worldwide and have been found predominantly in Enterobacteriaceae, particularly in E. coli, Klebsiella pneumoniae, Proteus mirabilis and Salmonella typhimurium(5). In contrast to a previous report from Bangladesh(27), our study detected a much lower frequency of OXA-1 (13\%) and SHV (4.3\%) producers. CTX-M and SHV-type genes were reported in E. coli isolated from surface water in Bangladesh(45). PCR based methods were used to identify specific genes for various classes of beta-lactamases. Gene targeted for PCR and number of positive isolates for each gene are shown in Table 3. 
In this study, ESBL producers were the most prevalent comprising of $84.7 \%$, followed by AmpC beta-lactamase producers which contained 6\% and metallo betalactamase producers consisting of $1.5 \%$ E. coli. . Occurrence of ESBL production among E. coli strains is important as they form a major part of the commensal intestinal flora and serve as a reservoir of infection in the environment. Problem with emergence of ESBL is enhanced further by the fact that the ESBL trait can be transferable via plasmids to other organisms. Resistance genes to other agents like fluoroquinolones, aminoglycosides and trimethoprim-sulfamethoxazole may also be transferred by conjugation. Of all isolates in this study, $31.34 \%$ produced CTX-M, $25.7 \%$ produced TEM, $10.6 \%$ produced OXA-1and $5.8 \%$ produced SHV. A total of 15 of the test isolates produced multiple beta-lactamases as shown in Table 4 . Of these $6.7 \%$ contained $4,20 \%$ contained 3 and $73.3 \%$ contained 2 beta-lactamase genes (Table 4).

Table 3. Targeted gene and number of positive isolates for each gene of Escherichia coli.

\begin{tabular}{|c|c|c|c|}
\hline Class & $\begin{array}{l}\text { Target } \\
\text { gene }\end{array}$ & $\begin{array}{l}\text { Amplicon } \\
\text { size (bp) }\end{array}$ & Isolates of Escherichia coli (n, \%) \\
\hline B & BlandM & 621 & $2(\mathrm{n}=66,1.5 \%)$ \\
\hline $\mathrm{C}$ & BlaAmpC & 634 & $2,12,15,17(\mathrm{n}=66,6 \%)$ \\
\hline \multirow[t]{4}{*}{$\mathrm{A} / \mathrm{D}$} & Вlатем & 858 & $\begin{array}{l}4,10,14,15,17,20,21,24,25 \\
27,28,36,41,47,48(\mathrm{n}=66,22.7 \%)\end{array}$ \\
\hline & Blactх-м & 593 & $\begin{array}{l}2,19,20,26,27,30,31,33,34,35,38,41,42,46,47, \\
48(\mathrm{n}=66,24.2 \%)\end{array}$ \\
\hline & Blashv & 827 & $19,20(\mathrm{n}=2,4.3 \%)$ \\
\hline & BlaoxA-1 & 882 & $20,25,26,27,28,31(\mathrm{n}=6,9.1 \%)$ \\
\hline
\end{tabular}

Table 4. Presence of multiple beta-lactamase genes in tested isolates.

\begin{tabular}{|c|c|c|c|c|c|c|}
\hline & blactх-м & blaтем & blaoxA-1 & blashv & NDM & AmpC \\
\hline \multicolumn{7}{|c|}{ E. coli } \\
\hline 2 & + & - & - & - & + & + \\
\hline 12 & - & - & - & - & + & + \\
\hline 15 & - & - & - & - & + & + \\
\hline 17 & - & - & - & - & + & + \\
\hline 19 & + & - & - & + & - & - \\
\hline 20 & + & + & + & + & - & - \\
\hline 25 & - & + & + & - & - & - \\
\hline 26 & + & - & + & - & - & - \\
\hline 27 & + & + & + & - & - & - \\
\hline 28 & - & + & + & - & - & - \\
\hline 31 & + & - & + & - & - & - \\
\hline 41 & + & + & - & - & - & - \\
\hline 47 & + & + & - & - & - & - \\
\hline 48 & + & + & - & - & - & - \\
\hline
\end{tabular}


In this study, $50 \%$ of the E. coli strains contained plasmids of variable sizes (Fig. 2). However, there was no correlation between beta-lactam resistance and presence of plasmids. Production of ESBL is frequently reported to be plasmid encoded and bears clinical significance. Plasmids carrying ESBL genes may also carry genes for resistance to other antibiotics. Determining the presence of plasmids in ESBL bacteria and establishing co-relation between presence of plasmid and ESBL production is important because spread of resistance via plasmids can lead to outbreaks or endemic occurrence ${ }^{(46)}$. Plasmid profiles of all isolates were studied to demonstrate variation and epidemiological linkage among the ESBL producers. Plasmids were found in 50\% of E. coli. However, no correlation was found between presence of plasmids and pattern of resistance to beta-lactam antibiotics. About $56 \%$ of the plasmid-containing E. coli did not exhibit resistance to the beta-lactams. Thus it can be inferred that mechanisms of antibiotic resistance was mediated by chromosome-borne factors in addition to plasmidmediated genes, if any. Further analyses are needed to determine the exact location of beta-lactam resistance genes. We classified plasmids based on a boundary of $1.33 \mathrm{MDa}$, since the smallest plasmid clearly discernible in our gel from E. coli V157 (positive control) was of this size. Plasmids in the present study ranged in size between less than one $\mathrm{kb}$ to about $7 \mathrm{~kb}$. Prevalence of plasmids found in the present study was found to be different from previous findings ${ }^{(27,47)}$.

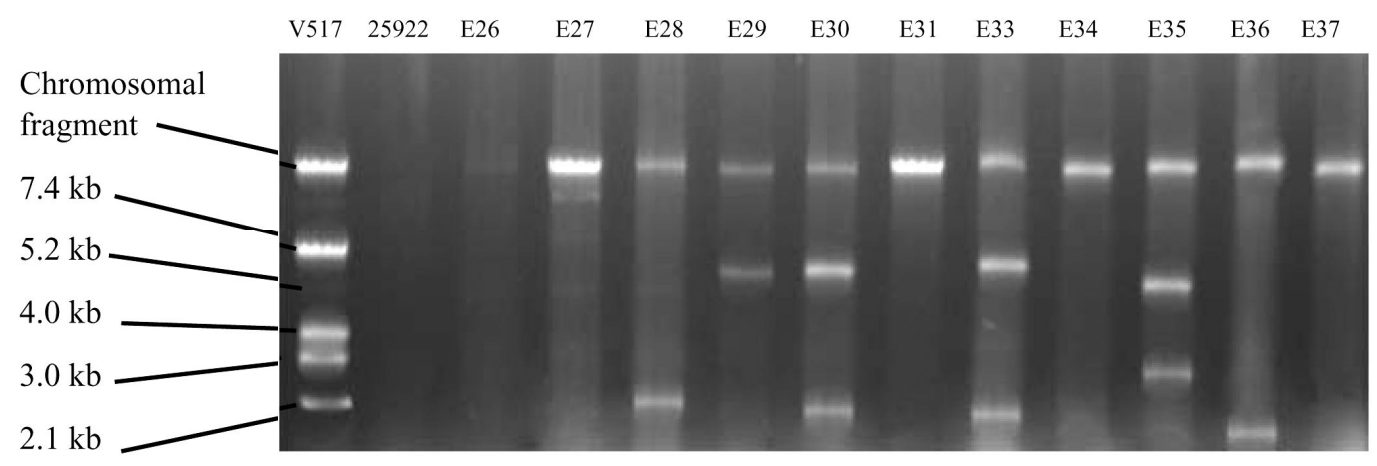

Fig. 2. Plasmid profile of test isolates. From left, lane 1: E. coli V517, lane 2: E. coli 25922, lanes 3-13:

Clinical E. coli investigated.

Integrons are mobile genetic elements which can carry beta-lactamase gene. A total of $39 \%$ of the E. coli isolates contained Class 1 integron. However, no correlation could be found between the occurrence of integron and beta-lactam resistance/plasmid. In our study, $39 \%$ of the E. coli isolates contained Class 1 integrons. A much higher prevalence of Class 1 integrons (50\%) was reported earlier ${ }^{(27)}$, who reported 50\% Class 1 integron containing ESBL producers.

Detection of ESBL producers is of significance because this facilitates adoption of treatment options. Spread of ESBL positive bacteria in the community and within 
hospitals may lead to endemic outbreaks. Moreover failure to treat ESBL infections limits therapeutic choices. It is imperative to investigate the prevalence of ESBL positive strains to formulate a policy to treat infections due to resistant organisms. The present study indicated a rising pattern of resistance to beta-lactam antibiotics when compared to earlier reports. Prevalence of beta-lactamase producing E. coli isolates reflects the overuse and misuse of antibiotics in Bangladesh. This limits therapeutic options for treatment. It is necessary to continuously monitor multi-drug resistant bacteria causing various infections to aid appropriate treatment strategies. Based on the findings of the present study, carbapenems still remain the drug of choice for treatment when choosing beta lactams. However, future studies need to be performed to determine the prevalence of other metallo beta-lactamases viz. IMP, VIM and SPM. The lack of correlation between mobile genetic determinants and antibiotic resistance emphasizes the need to actually locate the position of resistance genes for epidemiological significance.

\section{Acknowledgements}

This work forms part of the thesis of M.Sc. The authors are grateful to the Department of Microbiology, University of Dhaka, Bangladesh for laboratory facilities. They also thank Medinova Diagnostics Ltd. for providing the test clinical isolates.

\section{References}

1. Bush K and PA Bradford 2016. $\beta$-Lactams and $\beta$-Lactamase Inhibitors: An Overview. Cold Spring Harb. Perspect. Med. 6(8). pii: a025247. doi: 10.1101/cshperspect.a025247.

2. Dashti AA, P West, R Paton and SG Amyes 2006. Characterization of extended spectrum betalactamase (ESBL)-producing Kuwait and UK strains identified by the Vitek system, and subsequent comparison of the Vitek system with other commercial ESBL-testing systems using these strains. J. Med. Microbiol. 55: 417-421.

3. Hernandez JR, L Martinez-Martinez, R Canton, TM Coque and A Pascual 2005. Nationwide study of Escherichia coli and Klebsiella pneumoniae producing extended-spectrum betalactamases in Spain. Antimicrob. Agents Chemother. 49: 2122-2125.

4. Mugnaioli C, F Luzzaro, F De Luca, G Brigante, M Perilli, G Amicosante and S Stefani, A Toniolo and GM Rossolini 2006. CTXM-type extended-spectrum beta-lactamases in Italy: molecular epidemiology of an emerging countrywide problem. Antimicrob. Agents Chemother. 50: 2700-2706.

5. Radice M, P Power, J Di Conza and G Gutkind 2002. Early dissemination of CTXM-derived enzymes in South America. Antimicrob. Agents Chemother. 46: 602-604.

6. Zamorano L, E Miró, C Juan, L Gómez, G Bou, JJ González-López, L Martínez-Martínez, B Aracil, MC Conejo, A Oliver and F Navarro 2015. Mobile genetic elements related to the diffusion of plasmid-mediated AmpC $\beta$-lactamases or carbapenemases from Enterobacteriaceae: findings from a multicenter study in Spain. Antimicrob. Agents Chemother. 59(9): 5260-6. doi: 10.1128/AAC.00562-15. 
7. Thakur S., N Pokhrel and M Sharma 2013. Prevalence of multidrug resistant Enterobacteriaceae and extended spectrum $\beta$ lactamase producing Escherichia coli in urinary tract infection. R.J.P.B.C.S. 4(2):1615-1624.

8. İsmail HT and Haydar Ö 2016. Occurrence and characteristics of extended spectrum betalactamases-producing Enterobacteriaceae from foods of animal origin. Braz. J. Microbiol. 47(2): 444-451. doi: 10.1016 ’.bjm.2015.11.034.

9.Arlet G, G Brami, D Decré, A Flippo, O Gailloto, PH Lagrange and A Philippon 1995. Molecular characterisation by PCR-fragment length polymorphism of TEM $\beta$-lactamase.FEMS Microbiol. Lett. 134: 203-208.

10. Pagani L, E Dell'Amico, R Migliavacca, MM D'Andrea, E Giacobone, G Amicosante, E Romero and GM Rossolini 2003. Multiple CTX-M-type extended-spectrum beta-lactamases in nosocomial isolates of Enterobacteriaceae from a hospital in northern Italy. J. Clin. Microbiol. 41(9): 4264-9.

11. Chanawong A, FH M'Zali, J Heritage, A Lulitanond and PM Hawkey 2000. Characterisation of extended-spectrum beta-lactamases of the SHV family using a combination of PCR-single strand conformational polymorphism (PCR-SSCP) and PCR-restriction fragment length polymorphism (PCR-RFLP). FEMS Microbiol. Lett. 184(1): 85-9.

12. Shacheraghi $F$, MR Shakibaie and $H$ Noveiri 2010. Molecular Identification of ESBL genes blaGES-1, blaVEB-1, blaCTX-M blaOXA-1, blaOXA-4, blaOXA-10 and blaPER-1 in Pseudomonas aeruginosa strains isolated from burn patients by PCR, RFLP and sequencing techniques. Int. J. Biol. life Sci. 3(6): 138-42.

13. Yigit H, AM Queenan, GJ Anderson, A Domenech-Sanchez, JW Biddle, CD Steward, S Alberti, K Bush and FC Tenover 2001. Novel Carbapenem-Hydrolyzing $\beta$-Lactamase, KPC-1, from a Carbapenem-Resistant Strain of Klebsiella pneumoniae. Antimicrob. Agents Chemother. 45(4): 1151-1161.

14. Shahid M, S Farrukha, K Anuradhaa, M Haris, P Hawkey, A Huq and N Khardori 2009. AmpC $\beta$-lactamases and bacterial resistance: an updated mini review. Rev. Med. Microbiol. 20(3): 41-55.

15. Karuniawati A, R Yulia, Delly S and Lestari C 2013. Detection of Carbapenemase Encoding Genes in Enterobacteriace, Pseudomonas aeruginosa, and Acinetobacter baumanii Isolated from Patients at Intensive Care Unit Cipto Mangunkusumo Hospital in 2011. Acta Med. Indones-Indones. J. Intern. Med. 45(2): 101-106.

16. Guerra B, S Soto, S Cal and MC Mendoza 2000. Antimicrobial resistance and spread of Class 1 integrons among Salmonella serotypes. Antimicrob. Agents Chemother. 44(8): 2166-2169.

18.Birnboim HC and Doly J 1979. A rapid alkaline extraction procedure for screening recombinant plasmid DNA. Nucleic Acids Res. 7(6): 1513-1523.

19. Myat TO, RF Hannaway, KN Zin, WW Htike, KK Win, JA Crump, DR Murdoch and JE Ussher 2017. ESBL- and Carbapenemase-Producing Enterobacteriaceae in Patients with Bacteremia, Yangon, Myanmar, 2014. Emerg. Infect. Dis. 23(5):857-859. doi: 10.3201/eid2305.161100.

20. Chander A and CD Shrestha 2013. Prevalence of extended spectrum beta lactamase producing Escherichia coli and Klebsiella pneumoniae urinary isolates in a tertiary care hospital in Kathmandu, Nepal. BMC Res. Notes. 6:487. doi: 10.1186/1756-0500-6-487. 
21. Ryoo NH, EC Kim, SG Hong, YJ Park, K Lee, IK Bae, EH Song and SH Jeong 2005. Dissemination of SHV-12 and CTX-M-type extended spectrum beta lactamases among clinical isolates of Escherichia coli and Klebsiella pneumoniae and emergence of GES-3 in Korea. J. Antimicrob. Chemother. 56: 698-702.

22. Nakamura T and M Komatsu 2005. Susceptibility of ESBL producing E. coli and Klebsiella pneumoniae to various antibacterial agents. Japanese J. Antibiot. 58(1): 1-10.

23. Ambler RP 1980. The Structure of $\beta$-Lactamases. Phil. Trans. R. Soc. Lond. 289: 321-331.

24. Rahman MM, JA Haq, MA Hossain, R Sultana. F Islam and AH Islam 2004. Prevalence of extended-spectrum beta-lactamases-producing Escherichia coli and Klebsiella pneumoniae in an urban hospital in Dhaka, Bangladesh. Int. J. Antimicrob. Agents. 24: 508-510

25. Alim R 2005. Detection of Extended Spectrum Beta-Lactamases (ESBL) Producing Bacteria. [M. Phil Thesis, Microbiology] BSMMU, Dhaka.

26. Mostaquim R 2007. Rapid Detection of Extended Spectrum Beta-Lactamases (ESBL) Production Directly From Primary Culture. M.Phil.Thesis, BSMMU.

27. Lina TT, Khajanchi BK, Azmi IJ, Islam MA, Belal M, Akter M, Banik A, Alim R, Navarro A, Perez G, Cravioto A and Talukder KA 2014. Phenotypic and Molecular Characterization of Extended-Spectrum Beta-Lactamase Producing Escherichia coli in Bangladesh. PLoS ONE 9(10): e108735. doi:10.1371 journal.pone.0108735

28. Islam S, A Yusuf, SA Begum, A Sattar, A Hossain and S Roy 2015. Extended-spectrum-betalactamase producing uropathogenic Escherichia coli infection in Dhaka, Bangladesh. J. Bacteriol. Res. 7(1): 1-7.

29. Mehrgan H and M Rahbar 2008. Prevalence of extended-spectrum beta-lactamase-producing Escherichia coli isolated from community-acquired urinary tract infections in Dhaka, Senegal. J. Antimicrob. Chemother. 56: 236-239.

30. Ranjini CY, LR Kasukurthi, B Madhumati and R Rajendran 2016. Prevalence of multidrug resistance and extended spectrum beta-lactamses among uropathogenic Escherichia coli isolates in a tertiary care hospital in South India: An alarming trend. Community Acquir. Infect. 2(1): 19-24.

31. Mekki AH, AN Hassan and DE Elsayed 2010. Extended spectrum beta lactamases among multi drug resistant Escherichia coli and Klebsiella species causing urinary tract infections in Khartoum. J. Bacteriol. Res. 2: 18-21.

32. Mohammed A, S Mohammed and K Asad 2007. Etiology and antibiotic resistance patterns of community-acquired urinary tract infections in JNMC Hospital Aligarh, India. Ann. Clin. Microbiol. Antimicrob. 6: 17.

33. Taneja N, P Rao, J Arora and A Dogra 2008. Occurrence of ESBL \& Amp-C b-lactamases \& susceptibility to newer antimicrobial agents in complicated UTI. Indian J. Med. Res. 127(1): 85-88.

34. Ullah F, Malik SA and Ahmed J 2009. Antibiotic susceptibility pattern and ESBL prevalence in nosocomial Escherichia coli from urinary tract infections in Pakistan. African J. Biotech. 8(16): 3921-3926.

35. Barakha AT and Baragundi M 2015. Bacteriological Profile, Antibiotic Sensitivity Pattern and Detection of ESBL Production in the Isolates of UTI in Tertiary Care Hospital, Davangere, India. Int. J. Sci. Res.4(7): 1312-1317. ISSN (Online): 2319-7064. 
36. Bashir D, M Thokar, B Fomda, G Bashir, D Zahoor, S Ahmad and Toboli SA 2011. Detection of Metallo-beta-lactamase (MBL) producing Pseudomonas aeruginosa at a tertiary care hospital in Kashmir. African J. Microbiol. Res. 5: 164-172.

37. Bush K and GA Jacoby 2010. Updated functional classification of $\beta$-lactamases. Antimicrob. Agents Chemother. 54: 969-976.

38. Wang Z, W Fast, AM Valentine and SJ Benkovic 1999. Metallo-beta-lactamase: structure and mechanism. J. Curr. Opin. Chem. Bio. 3(5): 614-622

39. Bebrone C 2007. Metallo-beta-lactamases (classification, activity, genetic organization, structure, zinc coordination) and their superfamily. Biochem. Pharmacol. 74(12): 1686-701.

40. Kumarasamy KK, MA Toleman, TR Walsh, J Bagaria, F Butt, R Balakrishnan, U Chaudhary, M Doumith, CG Giske, S Irfan, P Krishnan, AV Kumar, S, Maharjan, S Mushtaq, T Noorie, DL Paterson, A Pearson, C Perry, R Pike, B Rao, U Ray, JB Sarma, M Sharma, E Sheridan, MA Thirunarayan, J Turton, S Upadhyay, M Warner, W Welfare, DM Livermore and N Woodford2010. Emergence of a new antibiotic resistance mechanism in India, Pakistan, and the UK: a molecular, biological, and epidemiological study. Lancet Infect. Dis. 10: 597-602.

41. Islam MA, PK Talukdar, A Hoque, M Huq, A Nabi, D Ahmed, KA Talukder, MA Pietroni, JP Hays, A Cravioto, HP Endtz 2012. Emergence of multidrug-resistant NDM-1-producing Gram-negative bacteria in Bangladesh. Eur. J. Clin. Microbiol. Infect. Dis. 31(10): 2593-600.

42. Day KM, S Ali, IA Mirza, HE Sidjabat, A Silvey, CV Lanyon, SP Cummings, SA Abbasi, MW Raza, DL Paterson, JD Perry 2013. Prevalence and molecular characterization of Enterobacteriaceae producing NDM-1 carbapenemase at a military hospital in Pakistan and evaluation of two chromogenic media. Diagn. Microbiol. Infect. Dis. 75(2): 187-91.

43. Rolain JM, P Parola and Cornaglia G. 2010. New Delhi metallo-beta-lactamase (NDM-1): towards a new pandemia? Clin. Microbiol. Infect. 16: 1699-1701.

44. Rawat D and D Nair 2010. Extended-spectrum $\beta$-lactamases in Gram Negative Bacteria. J. Glob. Infect. Dis. 2(3): 263-274. doi: 10.4103/0974-777X.68531.

45. Haque A, A Yoshizumi, T Saga, Y Ishii and K Tateda 2014. ESBL-producing Enterobacteriaceae in environmental water in Dhaka, Bangladesh. J. Infect. Chemother. 20(11): 735-737.

46. Meyer KS, C Urban, JA Eagan, BJ Berger and JJ Rahal 1993. Nosocomial outbreak of Klebsiella infection resistant to late generation cephalosporins. Ann. Int. Med. 119(5): 353-358.

47. Jacoby GA and L Sutton 1991. Properties of plasmids responsible for production of extended-spectrum beta-lactamases. Antimicrob. Agents Chemother. 35: 164-169. 